https://doi.org/10.52837/27382702-2021-34.2-08

\title{
SHANGHAI COOPERATION ORGANIZATION AS A PLATFORM FOR PROMOTING THE AGENDA OF CHINA'S BELT AND ROAD INITIATIVE*
}

\author{
Aram Abajyan
}

\begin{abstract}
The article discusses main issues and tendencies of two China-proposed initiatives, namely Shanghai Cooperation Organization (SCO) and Belt and Road Initiative (BRI). The key focus of the research combines the major points and expected results of BRI and the growing role of SCO in current International Relations. While exploring these two structures, we conclude that SCO is pushing forward BRI, serving as a strong influential and effective platform.

The organization helped China to build up unprecedentedly intense ties with local states, creating natural conditions to play an active and constructive role in BRI agenda. From the very beginning Chinese BRI is closely related with SCO sharing reciprocal approaches, common features, principles and goals. They are historically linked together both geographically and ideologically. Specific projects under BRI together with the existing economic cooperation structure of SCO are truly complementing each other. SCO members view the BRI favorably, and China's effective usage of the SCO has already resulted in many of its foreign policy goals being reached or at least had significant progress.
\end{abstract}

Keywords: Shanghai Cooperation Organization, Belt and Road Initiative, Central Asia, megaproject, platform, International Relations, agenda.

\section{Introduction}

The modern system of International Relations is passing through a stage of profound transformation and evolutionary development. In recent decades globalization has emerged as the main trend in world politics strengthening relations between the countries and the regions of the world. Rapid development of modern technologies in areas of communications, infrastructures, transport and information delivery is creating cohesive global community of states.

In the $21^{\text {st }}$ century systematic global move to a multipolar world system along with China's dramatic economic rise reinforced Beijing's unique and special position in International Politics. In that sense, former President Hu Jintao and Prime Minister Wen Jiabao were using "Peaceful Rise" and "Peaceful Development" foreign policy concepts to indicate, that the country would not become a global threat, but would be a constructive member of international community. Since then, Academic debates about China's international role

\footnotetext{
* The article was submitted on November 29, 2021: The article was reviewed on December 2, 2021.
} 
emerged in the West, particularly focusing on the core theories of International Relations-Realism and Liberal Institutionalism. While the first School viewed Beijing's nationalist foreign policy agenda as a global threat, the second considered China as transitioning to market democracy within global interdependence. The debate about China's rise and foreign policy entered a new phase especially in 2013, when Chinese "One Belt, One Road" (OBOR) Initiative was launched". The country began "Marching West" strategy, and on September 2013 at Kazakhstan's Nazarbayev University Chinese President Xi Jinping declared, that the 'Ancient Silk Road was full of new vitality with rapid development of China's relations with Asian and European countries, ${ }^{2}$. He suggested China and Eurasian partners jointly build a "New Silk Road Economic Belt", then continued his speech at the People's Representative Council of Indonesia by proposing a " $21^{\text {st }}$ Century Maritime Silk Road Initiative". The two projects were later evolved into the "Belt and Road Initiative" (BRI), creating bilateral and multilateral cooperative mechanism. While some Western scholars prefer to use the term "One Belt, One Road" instead of "Belt and Road", Beijing persists on the second in order to emphasize, that the initiative is not only Chinese own, and it is open for other international players too ${ }^{3}$.

\section{Belt and Road Megaproject: main points and expected perspectives}

The Belt and Road Initiative is a development strategy presenting China's entry into a relatively new level of global reforms and openness. The promotion of socioeconomic development calls for new approaches, measures, and the BRI strategy is ideally expressing more open approach to the development of China and its regions. Such a coordinated policy remains Beijing's basic principle ${ }^{4}$.

Through this extremely ambitious initiative Beijing is strengthening its connectivity with the world, meantime trying to become number one economic superpower until $2050^{5}$. It is a huge economic megaproject with the purpose of building a trade and infrastructure network connecting Asia with Europe and Africa along the ancient trade routes. The Silk Road Economic Belt (SREB) focuses on bringing together China, Central Asia, Russia and Europe (the

1 Tzogopoulos 2017: 7. Greece, Israel, and China's "Belt and Road" Initiative, Available at: http://www.jstor.com/stable/resrep04721.5

${ }^{2}$ President Xi Jinping Delivers Important Speech and Proposes to Build a Silk Road Economic Belt with Central Asian Countries 2013: MFA of the PRC, Available at: https://www.fmprc.gov.cn/mfa_eng/topics_665678/xjpfwzysiesgjtfhshzzfh_665686/t1076334.shtml

3 Tzogopoulos 2017: 7. Greece, Israel, and China's "Belt and Road" Initiative, Available at: http://www.jstor.com/stable/resrep04721.5

${ }^{4}$ Li 2018: 95. The greater Eurasian partnership and the Belt and Road Initiative, Available at: https://reader.elsevier.com/reader/sd/pii/S1879366518300198?token=E86788C45CD9C5D6B311902 75BF92AE2EFE341202459000FD7788C69E6B13063833784D84C808A80CD4E3D0A91B061AB\& originRegion $=$ eu-west- 1 \&originCreation $=20210810111345$

5 Nomani 2021: Chinese diplomacy: The Belt and Road Initiative, Available at: https://www.theindependentbd.com/post/259014 
Baltic), linking China with the Persian Gulf and the Mediterranean Sea through Central Asia and West Asia, also connecting China with Southeast Asia, South Asia and the Indian Ocean ${ }^{1}$. It is a long-term vision for the infrastructural development, connectivity and economic cooperation of Eurasia, including six development corridors, namely:

1. New Eurasian Land Bridge Economic Corridor (NELBEC)

2. China - Mongolia - Russia Economic Corridor (CMREC)

3. China - Central Asia - West Asia Economic Corridor (CCWAEC)

4. China - Indochina Peninsula Economic Corridor (CICPEC)

5. Bangladesh - China - India - Myanmar Economic Corridor (BCIMEC)

6. China - Pakistan Economic Corridor (CPEC)

The second component of the BRI (the $\mathbf{2 1}^{\text {st }}$ Century Maritime Silk Road) is intended to go from China's coast to Europe through the South China Sea and the Indian Ocean in one direction, and from China's coast through the South China Sea to the South Pacific in the other, connecting China to Southeast Asia, Indonesia, India, the Arabian Peninsula, Somalia, Egypt and Europe, encompassing the South China Sea, Strait of Malacca, Indian Ocean, Gulf of Bengal, Arabian Sea, Persian Gulf and the Red Sea ${ }^{2}$.

SREB is an extensive megaproject to build a single Eurasian economic, trade space and a transcontinental transport corridor. Its aim is to maximally enlarge international economic and trade cooperation, focusing on the following key aspects of cooperation: coordinate infrastructure development policies, expand investment and trade relations, enhance financial collaboration, increase social and cultural exchanges. However, most attention of the project is devoted to the development of infrastructures, such as railways, roads, ports, energy systems, telecommunication networks ${ }^{3}$.

Undoubtedly, financial integration and cooperation is an essential underpinning for the success of the initiative. Therefore, various banks, funds and financial institutions are heavily investing in the project, such as policy banks, state owned banks, state owned funds and international financing institutions. For instance, China set up a 40 billion USD Silk Road Fund that experts believe will open for investment in near future. The main focus is the construction of roads, railways, ports and airports across Central Asia and South Asia. Nevertheless, to fully fund the total BRI project volume of estimated 4 to 8 trillion USD, different funding channels such as BRI bonds, private capital investment, Public-Private

\footnotetext{
1 Tzogopoulos 2017: 8. Greece, Israel, and China's "Belt and Road" Initiative, Available at: http://www.jstor.com/stable/resrep04721.5

${ }^{2}$ Belt and Road Initiative, Available at: https://www.beltroad-initiative.com/belt-and-road/

${ }^{3}$ Wade, China's 'One Belt, One Road' initiative, Foreign Affairs, Defence and Security, Available at:

https://www.aph.gov.au/about_parliament/parliamentary_departments/parliamentary_library/pubs/bri efingbook $45 \mathrm{p} /$ chinasroad
} 
Partnerships (PPP) and State-Owned Enterprise (SOE) investment will be crucial for final success ${ }^{4}$.

In 2015 China announced the implementation plan of the "Vision and Actions on jointly building Silk Road Economic Belt and 21st Century Maritime Silk Road". According to the document, Chinese project aims to ensure a global free trade regime and an open world economy in the spirit of open regional cooperation $^{5}$.

In general, Belt and Road megaproject is a systematic agenda meeting the interests of all countries involved. It aims to jointly embrace the trend towards multipolar world, economic globalization, cultural diversity and IT development in the spirit of open regional cooperation. The initiative seeks mutual benefit and a conjunction of interests for cooperation in order to give full play to the strengths and potentials of all its participants ${ }^{6}$.

\section{Growing influence of Shanghai Cooperation Organization in current International Relations}

As we know, China's foreign policy agenda in Central Asia is mainly conditioned by economic interests, especially its desire to secure much needed energy security and the use of transit potential of the region. At the same time, it is trying to maintain stability and security in its Xinjiang Uygur Autonomous Region (XUAR). As China's economic participation in Central Asia continues to expand, its influence in the region is steadily increasing without injuring its main Eurasian strategic partner's-Russia's interests. Meanwhile, China and Central Asian states are gaining reciprocal benefits from cooperation. The trade with China and Chinese investments are the main catalyst for the region's economic growth ${ }^{7}$.

In Central Asia Chinese-initiated Shanghai Cooperation Organization (SCO) as a strong influential platform helped China to build up unprecedentedly intense ties with local states, creating natural conditions to play an active and constructive role in the region. The SCO is a Eurasian political, economic and security alliance formed in June $2001^{8}$. It has eight permanent member states (China, Russia,

\footnotetext{
${ }^{4}$ Belt and Road Initiative, Available at: https://www.beltroad-initiative.com/belt-and-road/

${ }^{5}$ Vision and Actions on Jointly Building Silk Road Economic Belt and 21st-Century Maritime Silk Road, 2015: National Development and Reform Commission, Ministry of Foreign Affairs, and Ministry of Commerce of the People's Republic of China with State Council authorization, Available at:

https://www.fmprc.gov.cn/mfa_eng/zxxx_662805/t1249618.shtml

${ }^{6}$ Wolff 2016: 4.

${ }^{7}$ Sulimanov, Beloglazov 2018: 149. Geopolitical interests of China in Central Asia, Available at: http://revista.sangregorio.edu.ec/index.php/REVISTASANGREGORIO/article/view/761/19-

AZAMAT

${ }^{8}$ Devonshire-Ellis 2017: The New Eurasian Age - China's OBOR, The Eurasian Economic Union, and Shanghai Co-Operation Organisation, Available at: https://www.silkroadbriefing.com/news/2017/08/15/new-eurasian-age-chinas-obor-eurasianeconomic-union-shanghai-co-operation-organisation-complimentary-white-paper-download/
} 
Kazakhstan, Kyrgyzstan, Tajikistan, Uzbekistan, India, Pakistan), four observer states (Iran, Afghanistan, Belarus, Mongolia) and six dialogue partners (Armenia, Azerbaijan, Turkey, Nepal, Cambodia, Sri Lanka) ${ }^{9}$. Most recently Iran also came one step closer for becoming a full member of SCO, but Tehran's accession process is expected to take up to two years to complete ${ }^{10}$. Actually, the final decision was made in 2021 to start the process of accepting Iran as a full member, meantime Egypt, Qatar and Saudi Arabia became dialogue partners of the organization ${ }^{11}$.

In terms of geographic area and population, the organization is the largest and one of the most powerful in the world ${ }^{12}$. In the Great Eurasian region the SCO is one of the most outstanding examples of new hybrid or mixed model of interstate regional partnership. The dynamics of the SCO development are driven primarily by vital necessity, multilateral agreements and the shared national interests of its members.

During Ufa Summit in 2015, the "SCO Development Strategy until 2025" was adopted with the purpose of expanding trade, economic and investment ties, as well as increasing joint project activities in fundamental areas of cooperation ${ }^{13}$. Thus, SCO is reaching a qualitatively new level distinguished by the increased effectiveness of cooperation and enhanced participation of the region's affairs, also in the process of global governance. By 2025 the SCO will strengthen its position in the global and regional architecture by actively working in support of building a polycentric democratic system of International Relations. The organization is steadily moving towards becoming the leading multilateral platform in the huge Eurasian landmass for the integrated discussion of issues related to the joint promotion of regional security, stability and the implementation of the UN "Sustainable Development Goals"14. The continued adherence to the principles of the "Shanghai spirit" is enhancing the image of the SCO as one of the effective, influential and responsible participant of modern multilateral diplomacy.

The enlargement of the SCO reflects the growing need of its members and other regional or international states and organizations for closer collaboration on the most essential security and development issues. Indeed, the effectiveness of the SCO largely depend on the common needs and joint efforts of its member states, as

\footnotetext{
${ }^{9}$ Devonshire-Ellis 2020: SCO Moscow Summit, Available at: https://www.silkroadbriefing.com/news/2020/09/11/china-india-to-stand-down-over-ladakh-after-sco-moscow-summit-talks-ongoingabout-post-covid-economic-recovery/

${ }^{10}$ Fathi 2021: What will SCO membership mean for Iran? Available at: https://www.mei.edu/publications/what-will-sco-membership-mean-iran

${ }^{11}$ Shanghai Cooperation Organization, Political and Peacebuilding Affairs, UNITED NATIONS, Available at: https://dppa.un.org/en/shanghai-cooperation-organization

12 Battams-Scott 2019: How Effective Is the SCO as a Tool for Chinese Foreign Policy? Available at: https://www.e-ir.info/2019/02/26/how-effective-is-the-sco-as-a-tool-for-chinese-foreign-policy/

${ }^{13}$ Alimov 2018: 123. The Shanghai Cooperation Organisation: Its role and place in the development of Eurasia, Available at: https://www.sciencedirect.com/science/article/pii/S1879366518300216

14 Norov 2021: SCO taking on greater importance in a multilateral world, Available at: https://www.chinadaily.com.cn/a/202104/28/WS6088f47ba31024ad0babb02e.html
} 
well as collective initiatives such as the "Greater Eurasian Partnership" proposed by Russia, and the BRI proposed by China ${ }^{15}$.

One of the most significant results of SCO was the accession of India and Pakistan as full-fledged members in $2017^{16}$. By bringing together four nuclear powers (China, Russia, India, Pakistan) the SCO format became an additional supporting element of the system for maintaining global strategic stability. As a result, the organization turned into a cornerstone of the Eurasian continent with its very powerful structure, which is firmly establishing itself as an influential and responsible participant in the current system of International Relations ${ }^{17}$.

\section{Shanghai Cooperation Organization is pushing forward Belt and Road Initiative}

In terms of geographic calculations, Central Asia is a key destination for China's BRI agenda. On the other hand, most founding members of another Chinese-initiated Shanghai Cooperation Organization are located in this region as well, so these two China-proposed projects are closely linked together geographically. As most of the SCO states are located along the Ancient Silk Road, it provides them a very advantageous location to actively participate in the initiative. The spirits and ideological bases of the two cooperation frameworks are in line with each other too. The spirit of the BRI emphasizes equality, solidarity, mutual trust, benefit, and cooperation in finding "win-win" solutions. These characteristics are ideally matched with the "Shanghai Spirit" of the SCO, which mainly focuses attention on equality, consultation, common development, mutual benefit, trust and respect for various cultures and civilizations ${ }^{18}$.

From the very beginning Chinese BRI is closely related with the SCO, and the two structures are sharing reciprocal approaches, common features, principles and goals. They are historically linked together both geographically and ideologically ${ }^{19}$.

Indeed, China's BRI is viewed as one of the most leading economic projects in contemporary world. It also becomes clear, how effective Chinese foreign policymakers implement the huge potential of SCO as a key tool for driving forward BRI agenda. The SCO serves as a multilateral platform and cooperative structure for Beijing to develop and upgrade infrastructures, strengthen China's bilateral ties in the region, improve institutions and drive much needed economic development. The specific projects under BRI and the existing economic cooperation structure of the SCO are truly complementing each other. The SCO is an effective platform for cooperation to strengthen multilateralism, rule of

\footnotetext{
${ }^{15}$ Jin, Dehang 2019: 79.

${ }^{16}$ Alimov 2018: 115.

Influence of Shanghai Spirit Continues to Grow 2021: Available at: https://www.beltandroad.news/influence-of-shanghai-spirit-continues-to-grow/

18 Rong 2018: SCO a natural partner to the Belt and Road Initiative, Available at: https://news.cgtn.com/news/3d3d414e3163544f77457a6333566d54/index.html

${ }^{19}$ Liangyu 2018: Economic Watch: SCO in closer ties with Belt and Road Initiative, Available at: http://www.xinhuanet.com/english/2018-06/09/c_137241789.htm
} 
international law, the UN Charter, and to further ensure equal, mutual, comprehensive, reliable security and sustainable economic development ${ }^{20}$.

So, it is not accidental that most of SCO members view the BRI favorably, and they have already shown their firm support. For instance, China and Russia issued a joint statement on May 2015 outlining the main approaches for linking the Silk Road Economic Belt (SREB) and the Eurasian Economic Union (EAEU) projects. Both parties believe, that it is necessary to use economic integration laws and actively enhance the role of the SCO to promote construction of the SREB, actively cooperate with the EAEU, create a Free Trade Area (FTA) in the AsiaPacific region (APR), and simultaneously begin creating a similar FTA among China, Russia and Central Asia ${ }^{21}$. Kazakhstan is also fully engaged in the BRI. Growing rail traffic between China and Europe has opened up new opportunities for Kazakhstan's "Special Economic Zones", such as Khorgos. Meantime, BRI strongly supports Kazakhstan's own national development policy, which is called "Nurly Zhol" (Bright Path). It is mainly focused on updating outdated infrastructure ${ }^{22}$. Central Asian other SCO member states (Tajikistan, Kyrgyzstan, Uzbekistan) welcomed BRI as well, participating in several large infrastructure development projects.

However, the SCO newcomer Pakistan remains the major and fundamental supporter of BRI. China promised to invest more than 60 billion USD in the country to build a modern infrastructure network. Trade between the two countries is gradually rising under BRI framework. Furthermore, China-Pakistan Economic Corridor (CPEC) is a flagship project under the initiative bringing benefits to local residents with the fulfilment of some projects, including construction of Port Qasim Coal-fired Power Plant and parts of Gwadar Port ${ }^{23}$.

Unlike Pakistan, the second SCO fresh giant-India, appeared to be the only member not to assist the initiative. It stated, that China-Pakistan Economic Corridor runs through Pakistan occupied Jammu and Kashmir territory, so it is unacceptable for India to participate in the project ${ }^{24}$. Nevertheless, despite the existing disputes, India will presumably show economic pragmatism and increase trade with its neighbors in order to promote the regional integration.

${ }^{20}$ India refuses to support China's Belt \& Road Initiative at SCO 2020: Available at: https://www.maritimegateway.com/india-refuses-support-chinas-belt-road-initiative-sco/

${ }^{21}$ Xi, Fang, Bing 2019: How the Belt and Road Initiative Can Help Strengthen the Role of the SCO and Deepen China's Cooperation with Russia and the Countries of Central Asia, Available at: https://journals.sagepub.com/doi/full/10.1177/0974928418821484

22 Goulard 2020: Reaffirmation of SCO support to the Belt and Road Initiative, One Belt One Road Europe 一带一路欧洲联盟, Available at: https://www.oboreurope.com/en/reaffirmation-sco-supportbri/

23 Rong 2018: SCO a natural partner to the Belt and Road Initiative, Available at: https://news.cgtn.com/news/3d3d414e3163544f77457a6333566d54/index.html

${ }_{24}$ Mohan 2020: India refuses to be part of China's 'One Belt, One Road' at SCO, Available at: https:/www.indiatoday.in/india/story/india-refuses-to-be-part-of-china-s-one-belt-one-road-at-sco1745536-2020-12-01 
Hence, the SCO's lasting support for the BRI and China's geographical proximity with Central Asian states, Russia, India and Pakistan, in a huge and profound level will promote openness, regional connectivity and cross-border transportation. Together with the SCO member countries China will constantly enrich and improve the cooperation content and methods of the BRI by actively operating national and regional development strategies ${ }^{25}$.

\section{Conclusion}

China's ambitious BRI is definitely a single massive foreign policy program in the entire history of China. Its gigantic network connectivity is going to make regional countries closer to each other through enhancing economic and trade cooperation, sharing culture and people-to-people contact, supporting a peaceful and prosperous environment. Meanwhile, the SCO platform provides numerous opportunities for China to accelerate the planning mechanism of the BRI. China can rebuild its security, economic and foreign policies regarding to BRI perspectives under the banner of the SCO. BRI will provide a favorable opportunity for Beijing to create a grand regional connectivity by using the platform of $\mathrm{SCO}$, as well as its influence in bilateral and multilateral relations.

China's usage of the SCO has already resulted in many of its foreign policy goals being reached or at least had significant progress. Once the regional security was at first place of Chinese foreign policy agenda, but through border forces reductions and focus on threats such as terrorism, regional stability has improved a lot. Now economic development has taken priority in the region, especially with the BRI. A number of major joint projects have already been completed in SCO member states under the framework of BRI, including highways, railways, tunnels, electric power plants, which improve cross-border logistics and promote trade.

During joint implementation of BRI, it became clear that the full-scale development of the SCO plays an important role as a mechanism in advancing business cooperation. The "Visions and Actions" document clearly states the need to strengthen the role of the mechanism of all-round cooperation and increase the importance of multilateral formats such as SCO. The Joint Declaration also calls China and Russia work together, primarily on the SCO platform.

The trends of Chinese-Russian growing strategic relations and economic cooperation in the framework of SCO and SREB are driving forward Eurasian continent. The realization of SREB on the base of SCO is becoming quite optimal, and the combination of these two mechanisms is going to create a new model of economic integration.

For China's Foreign Policy goals the effectiveness of SCO regarding BRI agenda is as such a subject for Academic debate, but the efforts and already made progress cannot be ignored, consequently, the role of SCO is absolutely successful.

\footnotetext{
${ }^{25}$ Rab, Zhilong 2019: 170. China and Shanghai Cooperation Organization (SCO): Belt and Road Initiative (BRI) Perspectives, Available at: http://www.ijhssnet.com/view.php? $\mathrm{u}=\mathrm{http}: / /-$ www.ijhssnet.com/journals/Vol_9_No_2_February_2019/21.pdf
} 


\section{BIBLIOGRAPHY}

Alimov R. 2018: The Shanghai Cooperation Organisation: Its role and place in the development of Eurasia, Journal of Eurasian Studies, Vol. 9, Issue 2, 114-124, Available at: https://www.sciencedirect.com/science/article/pii/S1879366518300216

Battams-Scott G. 2019: How Effective Is the SCO as a Tool for Chinese Foreign Policy?, E-INTERNATIONAL RELATIONS, Available at: https://www.e-ir.info/2019/02/26/how-effective-is-the-sco-as-a-tool-for-chinese-foreign-policy/

Belt and Road Initiative, Available at: https://www.beltroad-initiative.com/belt-and-road/

Devonshire-Ellis C. 2017: The New Eurasian Age - China's OBOR, The Eurasian Economic Union, and Shanghai Co-Operation Organisation: Complimentary White Paper Download, Silk Road Briefing, Available at: https://www.silkroadbriefing.com/news/2017/08/15/new-eurasian-age-chinas-obor-eurasian-economicunion-shanghai-co-operation-organisation-complimentary-white-paper-download/

Devonshire-Ellis C. 2020: SCO Moscow Summit: China \& India To Stand Down Over Ladakh, Seven Cooperation Points, Talks About Post-Covid Economic Recovery, Silk Road Briefing, Available at: https:/www.silkroadbriefing.com/news/2020/09/11/china-india-to-stand-down-over-ladakh-after-sco-moscow-summit-talksongoing-about-post-covid-economic-recovery/

Fathi N. 2021: What will SCO membership mean for Iran?, Middle East Institute, Available at: https:/www.mei.edu/publications/what-will-sco-membership-meaniran

Goulard S. 2020: Reaffirmation of SCO support to the Belt and Road Initiative, One Belt One Road Europe 一带一路欧洲联盟, Available at: https://www.oboreurope.com/en/reaffirmation-sco-support-bri/

India refuses to support China's Belt \& Road Initiative at SCO, South Asia's Premier Shipping \& Logistics News Portal, December 4, 2020, Available at: https:/www.maritimegateway.com/india-refuses-support-chinas-belt-road-initiative$\mathrm{sco} /$

Influence of Shanghai Spirit Continues to Grow, By Business Reporting Desk, March 26, 2021, Available at: https://www.beltandroad.news/influence-of-shanghai-spiritcontinues-to-grow/

Jin W., Dehang K. 2019: Counter-Terrorism Cooperation Between China and Central Asian States in the Shanghai Cooperation Organization, China Quart. of International Strategic Studies, Vol. 5, № 1, 65-79.

Liangyu 2018: Economic Watch: SCO in closer ties with Belt and Road Initiative, Xinhua, Available at: http://www.xinhuanet.com/english/2018-06/09/c_137241789.htm

Li Y. 2018: The greater Eurasian partnership and the Belt and Road Initiative: Can the two be linked?, Journal of Eurasian Studies, Vol. 9, 94-99, Available at: https://reader.elsevier.com/reader/sd/pii/S1879366518300198?token=E86788C45CD 9C5D6B31190275BF92AE2EFE341202459000FD7788C69E6B13063833784D84C 808A80CD4E3D0A91B061AB\&originRegion=eu-west-1\&originCreation=20210810111345

Mohan G. 2020: India refuses to be part of China's 'One Belt, One Road' at SCO, India Today, Available at: https://www.indiatoday.in/india/story/india-refuses-to-be-partof-china-s-one-belt-one-road-at-sco-1745536-2020-12-01 
Nomani S. 2021: Chinese diplomacy: The Belt and Road Initiative, Available at: https://www.theindependentbd.com/post/259014

Norov V. 2021: Secretary General of the Shanghai Cooperation Organization, SCO taking on greater importance in a multilateral world, China Daily. Available at: https://www.chinadaily.com.cn/a/202104/28/WS6088f47ba31024ad0babb02e.html

President Xi Jinping Delivers Important Speech and Proposes to Build a Silk Road Economic Belt with Central Asian Countries, Ministry of Foreign Affairs of the People's Republic of China, 2013/09/07, Available at:

https://www.fmprc.gov.cn/mfa_eng/topics_665678/xjpfwzysiesgjtfhshzzfh_665686/t10763 34.shtml

Rab A., Zhilong H. 2019: China and Shanghai Cooperation Organization (SCO): Belt and Road Initiative (BRI) Perspectives, International Journal of Humanities and Social Science, Vol. 9, No. 2, 170, Available at:

http://www.ijhssnet.com/view.php?u=http://www.ijhssnet.com/journals/Vol_9_No_2_Febr uary_2019/21.pdf

Rong G. 2018: SCO a natural partner to the Belt and Road Initiative, Available at: https://news.cgtn.com/news/3d3d414e3163544f77457a6333566d54/index.html

Shanghai Cooperation Organization, Political and Peacebuilding Affairs, UNITED NATIONS, Available at: https://dppa.un.org/en/shanghai-cooperation-organization

Sulimanov A., Beloglazov A. 2018: Geopolitical interests of China in Central Asia, Revista San Gregorio, 149. Available at: http://revista.sangregorio.edu.ec/index.php/REVISTASANGREGORIO/article/view/761/19-AZAMAT

Tzogopoulos G. 2017: Greece, Israel, and China's "Belt and Road" Initiative, Begin-Sadat Center for Strategic Studies, 7. Available at: http://www.jstor.com/stable/resrep04721.5

Vision and Actions on Jointly Building Silk Road Economic Belt and 21st-Century Maritime Silk Road 2015: National Development and Reform Commission, Ministry of Foreign Affairs, and Ministry of Commerce of the People's Republic of China with State Council authorization, Available at: https://www.fmprc.gov.cn/mfa_eng/zxxx_662805/t1249618.shtml

Wade G., China's 'One Belt, One Road' initiative, Foreign Affairs, Defence and Security, Available at:

https://www.aph.gov.au/about_parliament/parliamentary_departments/parliamentary_librar $\mathrm{y} /$ pubs/briefingbook $45 \mathrm{p} / \mathrm{chinasroad}$

Wolff P. 2016: China's 'Belt and Road' Initiative - Challenges and Opportunities, REPORT PREPARED FOR THE 2016 ANNUAL MEETING OF THE ASIAN DEVELOPMENT BANK, German Development Institute, 4.

Xi L., Fang H., Bing L. 2019: How the Belt and Road Initiative Can Help Strengthen the Role of the SCO and Deepen China's Cooperation with Russia and the Countries of Central Asia, Available at: https://journals.sagepub.com/doi/full/10.1177/0974928418821484 


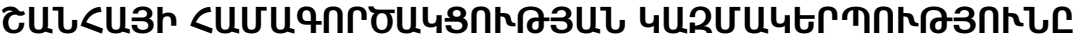

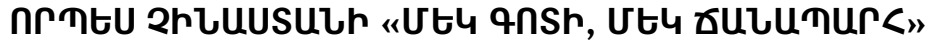

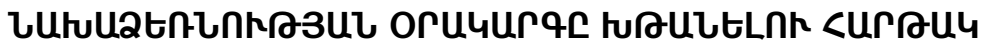

\section{Uршर Uршејшर}

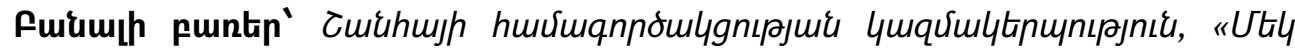

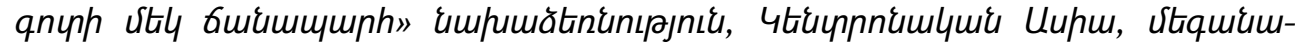

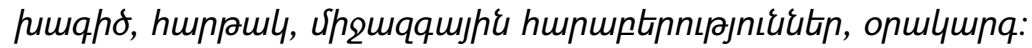

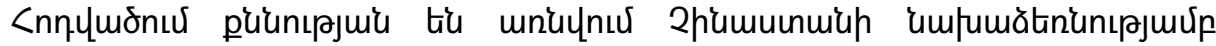

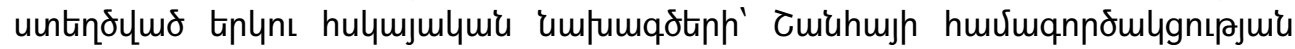

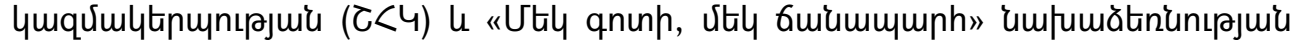

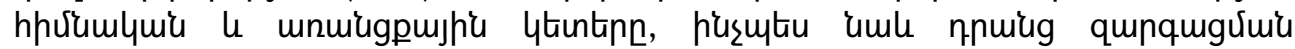

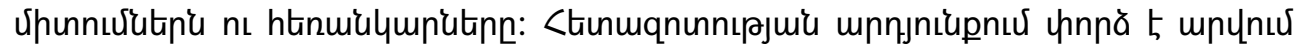

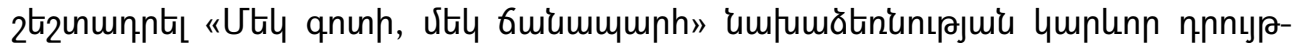

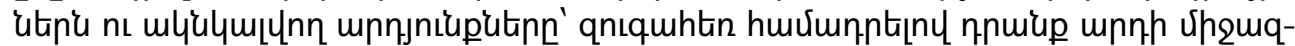

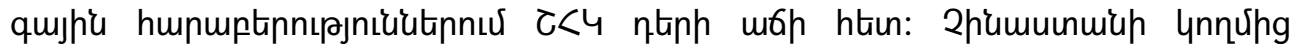

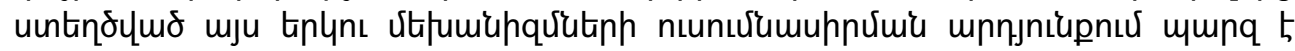

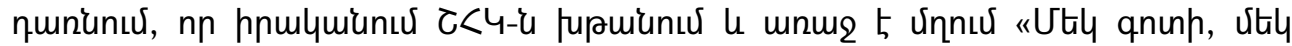

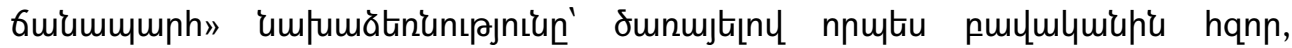

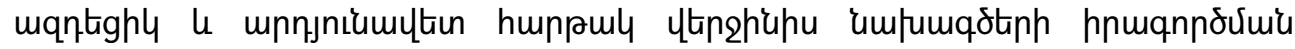
intumiulyniuhg:

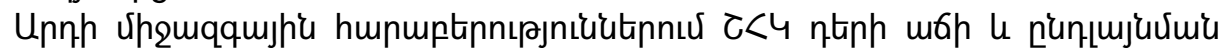

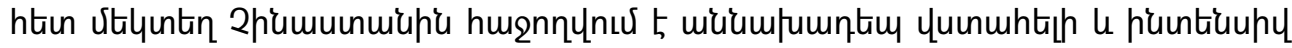

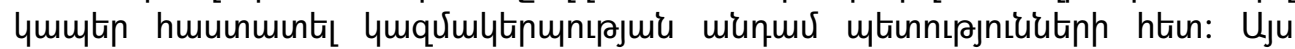

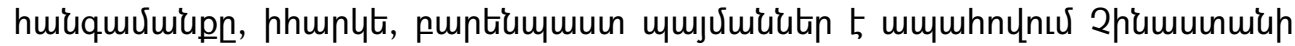

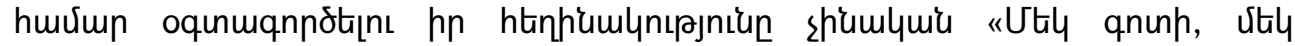

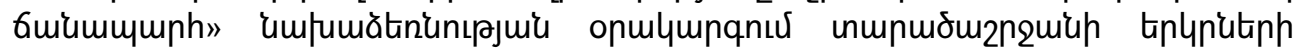

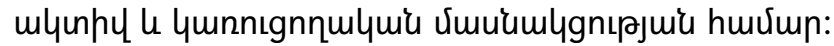

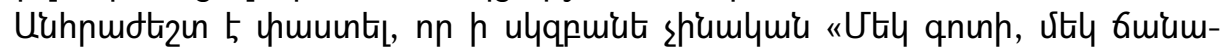

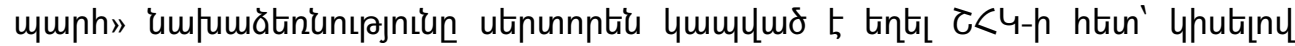

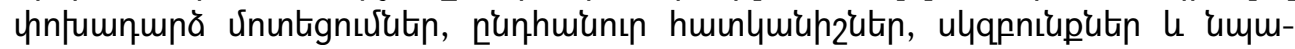

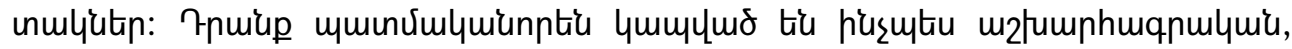

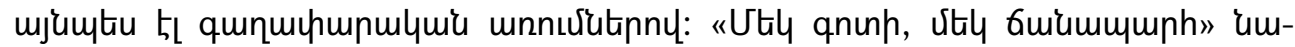
jumätnunı

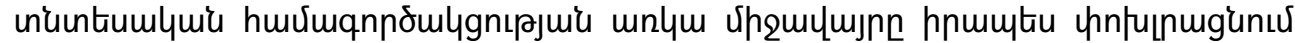
tiu upujuiug:

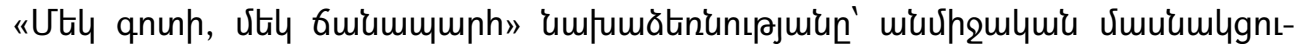

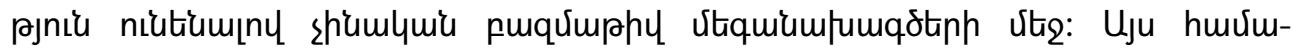

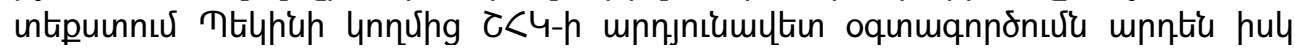

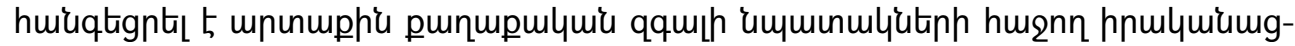

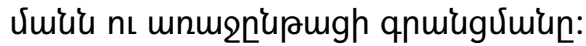

